Molecular imprinting of bovine serum albumin and lysozyme within the matrix of polyampholyte hydrogels based on acrylamide, sodium salt of 2-acrylamido-2-methyl-

1-propanesulfonic acid and (3-acrylamidopropyl) trimethyl ammonium chloride
Molecularly-imprinted polyampholyte (MIP) hydrogels based on nonionic monomer acrylamide (AAm), anionic monomer - sodium salt of 2-acrylamido-2-methyl-1-propanesulfonic acid (AMPS) and cationic monomer - (3-acrylamidopropyl)trimethyl ammonium chloride (APTAC) were obtained by immobilization of bovine serum albumin (BSA) and lysozyme in situ polymerization conditions. It was found that the best amphoteric hydrogel for sorption of BSA is APTAC-75H while for sorption of lysozyme is AMPS-75H. The sorption capacity of APTAC-75H and AMPS-75H with respect to BSA and lysozyme is 305.7 and $64.1-74.8 \mathrm{mg}$ per $1 \mathrm{~g}$ of hydroge respectively. Desorption of BSA and lysozyme from MIP template performed by aqueous solution of $1 \mathrm{M} \mathrm{NaCl}$ is equal to $82-88 \%$. Separation of BSA and lysozyme from their mixture was performed on MIP templates. The results of adsorption-desorption cycles of BSA on adjusted to BSA polyampholyte hydrogel APTAC-75H and of lysozyme on adjusted to lysozyme polyampholyte hydrogel AMPS-75H show that the mixture of BSA and lysozyme can be selectively separated with the help of MIP hydrogels.

Keywords: molecularly imprinted polyampholyte hydrogels; bovine serum albumin, lysozyme, sorption-desorption; separation of proteins.
A.V. Shakhvorostov*, S.E. Kudaibergenov

Institute of Polymer Materials and

Technology, Almaty, Kazakhstan

*E-mail: alex.hv91@gmail.com

\section{Акриламид, 2-акриламидо- \\ 2-метил-1-пропансульфон қышқылының натрий тұзы және \\ (3-акриламидопропил)- триметиламмоний хлориді негізіндегі полиамфолитті гидрогельдер матрицасынан бұқа сарысу альбумині (БСА) мен лизоцимнің молекулалық импринтингі}

А.В. Шахворостов*, С.Е. Құдайбергенов

Полимер материалдары және технологиялар институты, Алматы, Қазақстан *E-mail: alex.hv91@gmail.com
Бейионды мономер - акриламид (ААм), анионды мономер - 2-акриламидо-2метил-1-пропансульфон қышқылының натрий тұзы (АМПС) және катионды мономер - (З-акриламидопропил)-триметиламмоний хлориді (АПТАХ) негізіндегі молекулалық - импринтингті полиамфолитті гидрогелдерге (МИП) бұқа сарысу альбумині (БСА) мен лизоцимді in situ полимерлеу жағдайында иммобилизациялау арқылы синтезделді. Гидрогелдердің ақуыздарға қатысты максималды сорбциялық қасиеттері БСА үшін АПТАХ-75Г, ал лизоцим үшін АМПС-75Г екендігі анықталды. АПТАХ-75Г және АМПС-75Г гидрогельдердін БСА және лизоцим үшін сорбциялық сиымдылығы 1 г гидрогельге сәйкес 305,7 және 64,1-74,8 мг құрады. МИП гидрогель матрицасынан 1M NaCl сулы ерітіндісіне БСА және лизоцимнің десорбциялану дәрежесі 82-88\% құрайды. Ақуыздардың қоспасынан БСА және лизоцимді бөліп алу тәжірибелері жүргізілді. БСАны АПТАХ-75Г және лизоцимді АМПС-75Г МИП гидрогелдеріне бірнеше рет адсорбция-десорбция жасау арқылы, гидрогелдерді талғампаздыққа бейімдеп, оларды одан әрі селективті бөлуде қолдануға болатынын көрсетті.

Түйін сөздер: молекулалық-импринтингті полиамфолитті гидрогелдер; бұқа сарысу альбумині; лизоцим; сорбция-десорбция; ақуыздарды бөлу.

\section{Молекулярный импринтинг} бычьего сывороточного альбумина (БСА) и лизоцима в матрицу полиамфолитных гидрогелей на основе акриламида, натриевой соли

2-акриламидо-2-метил1-пропансульфоновой

кислоты и (3-акриламидопропил)триметиламмоний хлорида

А.В. Шахворостов*, С.Е. Кудайбергенов

Институт полимерных материалов и технологий, Алматы, Казахстан *E-mail: alex.hv91@gmail.com
Молекулярно-импринтированные полиамфолитные гидрогели (МИП) на основе неионогенного мономера - акриламида (ААМ), анионного мономера - натриевой соли 2-акриламидо-2-метил-1-пропансульфоновой кислоты (АМПС) и катионного мономера - хлорид (3-акриламидопропил)-триметиламмония (АПТАХ) получены путем иммобилизации бычьего сывороточного альбумина (БСА) и лизицома в условиях in situ полимеризации. Установлено, что максимальную сорбционную способность по отношению к БСА проявляет гидрогель АПТАХ-75Г, тогда как для лизоцима - гидрогель АМПС-75Г. Сорбционная емкость АПТАХ-75Г и АМПС-75Г по отношению к БСА и лизоциму составляет 305,7 и 64,1-74,8 Mг на 1 г гидрогеля соответственно. Степень десорбции БСА и лизоцима из матрицы МИП гидрогеля водным раствором $1 \mathrm{M} \mathrm{NaCl}$ составляет 82$88 \%$. Проведены эксперименты по разделению БСА и лизоцима из их смеси. Результать циклической адсорбции-десорбции БСА на МИП гидрогеле АПТАХ-75Г и лизоцима на МИП гидрогеле АМПС-75Г показывают, что смесь БСА и лизоцима может быть селективно разделена с помощью настроенных МИП гидрогелей.

Ключевые слова: молекулярно-импринтированные полиамфолитные гидрогели бычий сывороточный альбумин; лизоцим; сорбция-десорбция; разделение белков. 


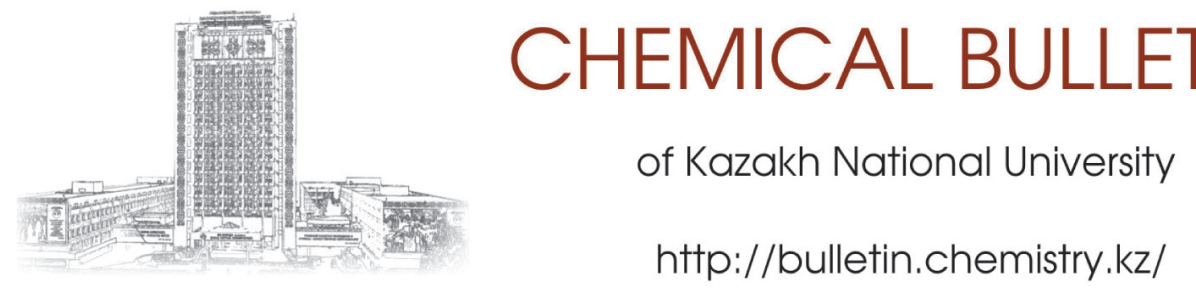

\title{
Molecular imprinting of bovine serum albumin and lysozyme within the matrix of polyampholyte hydrogels based on acrylamide, sodium salt of 2-acrylamido-2-methyl-1- propanesulfonic acid and (3-acrylamidopropyl)trimethyl ammonium chloride
}

\author{
A.V. Shakhvorostov* (D, S.E. Kudaibergenov \\ Institute of Polymer Materials and Technologies, 1/3 microdistrict "Atyrau 1", Almaty 050019, Kazakhstan \\ *E-mail:alex.hv91@gmail.com
}

(This paper is dedicated to $\mathbf{7 0}^{\text {th }}$ anniversary of Professor Sarkyt E. Kudaibergenov)

\section{Introduction}

Molecularly imprinted polyampholyte (MIP) hydrogels and cryogels [1] are perspective materials for biomedical applications [2-6]. Macroporous amphoteric polyampholytes based on $\mathrm{N}, \mathrm{N}$-dimethylaminoethyl methacrylate and methacrylic acid (MAA) [7], N-[3-(dimethylamino)propyl] methacrylate and MAA [8], N,N-dimethylaminopropylacrylamide and acrylic acid (AA) [9], acrylamide, methacrylic acid and $\mathrm{N}, \mathrm{N}$-dimethylaminoethylmethacrylate [10] were used as a templates, adsorbents and carriers with respect to bovine serum albumin (BSA), lysozyme and cytochrome $C$.

The imprinting capability of polyampholyte cryogels as templates with respect to lysozyme, pepsin, ovalbumin, hemoglobin, and $y$-globulin was compared [11]. An imprinting factor (IF) calculated by the formula: $\mathrm{IF}=\mathrm{k}_{\mathrm{MIP}} / \mathrm{k}_{\mathrm{NIP}}$ ( where $\mathrm{k}_{\mathrm{MIP}}$ and $\mathrm{k}_{\mathrm{NIP}}$ are the retention factors on the molecularly imprinted polyampholyte - MIP and non imprinted polyampholyte - NIP) changed in the following order: lysozyme > ovalbumin > hemoglobin $>$ pepsin $>\gamma$-globulin.

Molecularly imprinted polyampholyte hydrogel with respect to BSA was prepared from acrylamide (AAm), $\mathrm{N}$-isopropylacrylamide (NIPAM), [2-(methacryloyloxy)ethyl] trimethylammonium chloride (METMAC), and 2-acrylamido-2methyl-1-propanesulfonic acid (AMPS) monomers with MBAA as the crosslinker [12]. The morphology of molecularly imprinted polyampholyte hydrogels (MIPAHs) and non-imprinted polyampholyte hydrogels (NIPAHs) showed that the pore diameter of MIPAHs is larger than NIPAHs. The ideal conditions for preparing MIPAHs were found, including AAm concentration, NIPAM/AAm molar ratio, charge densitiy ratio (expressed as METMAC/AMPS molar ratio), and crosslinking density.

Earlier [13-15] we described the synthetic protocol of linear and crosslinked quenched polyampholytes based on sodium salt of 2-acrylamido-2-methyl-1-propanesulfonic acid (AMPS) and cationic monomer - (3-acrylamidopropyl)trimethyl ammonium chloride (APTAC), studied the behavior in aqueoussalt solutions, evaluated the swelling properties and complexation with respect to ionic dyes and surfactants. The rheological, mechanical and self-healing properties of hydrophobically-modified AMPS-APTAC hydrogels were investigated [16]. Behaviors of quenched polyampholytes in solution and gel state were also reviewed [17].

In spite of numerous publications devoted to imprinting of proteins within polyampholyte hydrogels available information on molecularly imprinted quenched polyampholytes for immobilization of biomacromolecules are frequently lacking. This paper considers the molecular imprinting of BSA and lysozyme within quenched polyampholyte hydrogels to develop the molecularly imprinted polyampholyte system for binding, separation and purification of target proteins from a mixture.

\section{Experiment}

2.1. Materials

Proteins - bovine serum albumin (BSA), lysozyme, and monomers - 2-acrylamido-2-methylpropanesulfonic acid 


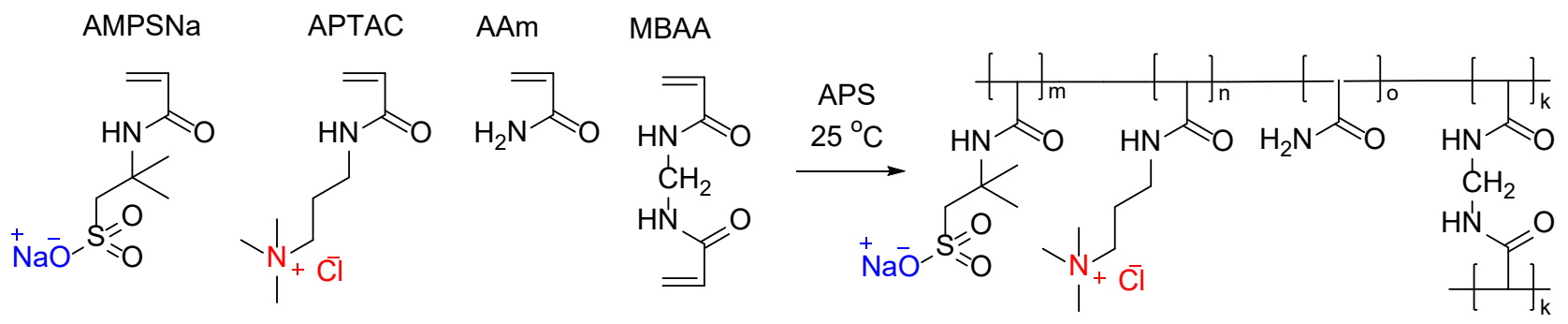

Figure 1 - Polymerization protocol of AMPS-75H and APTAC-75H hydrogels

sodium salt (AMPS, 50 wt.\%) and (3-acrylamidopropyl) trimethylammonium chloride (APTAC, $75 \mathrm{wt} . \%$ in water), acrylamide (AAm, 99\% purity), crosslinking agent $N, N^{\prime}$ methylenbisacrylamide (MBAA, 99\% purity), red-ox initiator $\left(\mathrm{Na}_{2} \mathrm{~S}_{2} \mathrm{O}_{5}-\mathrm{Na}_{2} \mathrm{~S}_{2} \mathrm{O}_{8^{\prime}}\right.$ 99\% purity) were purchased from SigmaAldrich Chemical Co., and used without further purification. Reagent grade sodium chloride, sodium hydroxide and hydrochloric acid were used.

\subsection{Methods}

UV-Vis spectra were recorded on UV-Vis spectroscopy (Specord 210 plus, Germany). FTIR spectra of samples were registered on a Cary 660 FTIR (Agilent, USA). Dynamic light scattering (DLS) and zeta-potential measurements were provided with the help of Zetasizer NanoZS 90 (Malvern, UK). pH of the solution was measured by 905 Titrando (Metrohm, Switzerland). Centrifugation of samples was carried out on the centrifuge Z 206 A (HERMLE Labortechnik, Germany) at 6000 r.p.m.

2.3. Synthesis of APTAC-AMPS-AAm (APTAC-75H) and AMPS-APTAC-AAm (AMPS-75H) polyampholyte hydrogels

APTAC-AMPS-AAm (APTAC-75H) and AMPS-APTAC-AAm (AMPS-75H) hydrogels were synthesized at various initial molar ratio of monomers and crosslinker (Figure 1). The content of charged monomers in APTAC- $75 \mathrm{H}$ was equal to 10 and $20 \mathrm{~mol} . \%$ while in AMPS-75H is 10 mol.\% respectively (Table 1 ).

After polymerization the AMPS-75H and APTAC- $75 \mathrm{H}$ hydrogel samples were washed sequentially using distilled and deionized water for one week, in order to remove the sol fraction.

Table 1 - Synthetic protocol of AMPS-75H and APTAC-75H hydrogels

\begin{tabular}{lllll}
\hline $\begin{array}{l}\text { Polyampholyte } \\
\text { hydrogels }\end{array}$ & $\begin{array}{l}\text { APTAC, } \\
\text { mol.\% }\end{array}$ & $\begin{array}{l}\text { AMPS, } \\
\text { mol.\% }\end{array}$ & $\begin{array}{l}\text { AAm, } \\
\text { mol.\% }\end{array}$ & $\begin{array}{l}\text { MBAA, } \\
\text { mol.\% }\end{array}$ \\
\hline APTAC-75H & 7.5 & 2.5 & 85 & 5 \\
APTAC-75H & 15 & 5 & 75 & 5 \\
AMPS-75H & 2.5 & 7.5 & 85 & 5 \\
\hline
\end{tabular}

2.4. Imprinting of proteins into the matrix of AMPS-75H and APTAC- $75 \mathrm{H}$ polyampholytic hydrogels

Imprinting of BSA and lysozyme within the strong charged polyampholyte hydrogels was carried out by the following scheme (Figure 2):

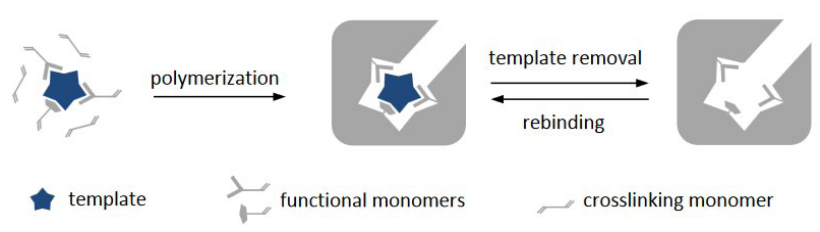

Figure 2-Immobilization scheme of proteins within the network of polyampholytes

The sense of molecular imprinting is that after removal of the template the leaving cavities possess size, shape and functional environment which are complementary to the target molecule. In our case the selected protein or enzyme was mixed with AMPS, APTAC and crosslinker - MBAA (5 mol.\%) and polymerized at room temperature. The template was removed by washing of hydrogel samples by $1 \mathrm{M} \mathrm{NaCl}$ several times. APTAC-75H with excess of cationic monomer was suitable for adsorption of BSA while AMPS-75H with excess of anionic monomer - for adsorption of lysozyme.

The synthetic protocol of MIP adjusted to BSA is the following. To vial containing $0.1 \mathrm{~g}$ of BSA preliminary dissolved in $20 \mathrm{~mL}$ of deionized water the monomers APTAC, AMPS, AAm and crosslinking agent MБAA were added, stirred $30 \mathrm{~min}$ and purged $20 \mathrm{~min}$ by nitrogen to remove the dissolved oxygen. After addition of red-ox initiator $\left(\mathrm{Na}_{2} \mathrm{~S}_{2} \mathrm{O}_{5}-\mathrm{Na}_{2} \mathrm{~S}_{2} \mathrm{O}_{8}\right)$, the mixture was stirred $20 \mathrm{sec}$ and the vial was sealed with screwing band. The mass concentration of monomers in mixture was equal to $10 \mathrm{~mol} . \%$. To avoid the denaturation of BSA, the polymerization reaction was carried out at room temperature during 18-20 h. The obtained monolithic gel sample was washed by deionized water and crushed through the sieve with mesh screen $125 \mu \mathrm{m}$.

For removal of the imprinted BSA from the AMPS- $75 \mathrm{H}$ hydrogel matrix $1 \mathrm{~g}$ of hydrogel paste was added to $20 \mathrm{~mL}$ of $1 \mathrm{M}$ $\mathrm{NaCl}$ solution and shaked in centrifugal shaker at 300-350 r.p.m. during $20 \mathrm{~min}$. The microgel particles were precipitated on 
centrifuge at 6000 r.p.m. and an aliquot was taken from the supernatant to determine the concentration of BSA by UV-Vis spectrophotometer at $279 \mathrm{~nm}$. The microgel particles were washed out by $1 \mathrm{M} \mathrm{NaCl}$ until disappearance of absorption peak of BSA in supernatant. The absence of BSA in supernatant was qualified as washing out of all imprinted BSA from hydrogel matrix.

The procedure described above was used for imprinting of lysozyme to and washing out from the polyampholyte hydrogel matrix APTAC-75H.

\subsection{Sorption of BSA and lysozyme by imprinted MIP}

Templated microgel particles preliminary adjusted to BSA (AMPS-75H) and/or lysozyme (APTAC-75H) were used afterwards for sorption of proteins. For this $10 \mathrm{~mL} 0.2 \mathrm{wt} . \% \mathrm{BSA}$ (or lysozyme) was added to templated microgel particles, shaked in centrifugal shaker at 300-350 r.p.m. during $20 \mathrm{~min}$. Then the mixture of BSA (or lysozyme) and microgel particles was centrifuged at 6000 r.p.m. during $10 \mathrm{~min}$. The supernatant was separated from the precipitate, weighed followed by determination of protein concentration at $\lambda=279 \mathrm{~nm}$. Such procedure was repeated until the concentration of protein in supernatant remained constant showing the completeness of adsorption process.

\subsection{Desorption of BSA and lysozyme from the MIP}

Desorption of BSA (or lysozyme) from the MIPs preliminary adjusted to BSA (AMPS-75H) and/or lysozyme (APTAC-75H) was performed as described in previous section. Threefold washing of AMPS-75H and APTAC- $75 \mathrm{H}$ by $1 \mathrm{M} \mathrm{NaCl}$ leads to full removal of BSA and lysozyme from imprinted hydrogel matrix.

\subsection{Separation of the mixture of BSA and lysozyme by} MIPs

For separation of the mixture of BSA and lysozyme by MIPs the following experiments were carried out. $10 \mathrm{~mL}$ 0.1 wt.\% mixture of BSA and lysozyme was added to templated microgel particles AMPS-75H adjusted to BSA or to templated microgel particles APTAC-75H adjusted to lysozyme, shaked in centrifugal shaker at 300-350 r.p.m. during $20 \mathrm{~min}$. Then the microgel particles was centrifuged at 6000 r.p.m. during $10 \mathrm{~min}$. The supernatant was separated from the precipitate followed by determination of the isoelectric points of proteins and concentrations at $\lambda=279 \mathrm{~nm}$.

2.8. Determination of the isoelectric points (IEPs) of BSA and lysozyme in water

The IEPs of BSA and lysozyme were determined in aqueous solution measuring the $\mathrm{pH}$ dependence of zeta-potential. In our case the values of the IEPs of BSA and lysozyme determined by zeta-potential measurement were equal to 4.58 and $\approx 10$ respectively. However the IEP of lysozyme deviates from the value of the IEP determined at the ionic strength $0.1\left(\mathrm{pH}_{\text {IEP }}\right.$ 11.3) [18]. This is probably due to different ionization degree of acidbase groups of lysozyme in pure water and saline solution.

\section{Results and Discussion}

Figure 3 shows the amount of removed BSA during three times washing of APTAC-75H crosslinked by 10 and 20 mol.\% of MBAA by $0.1 \mathrm{M} \mathrm{NaCl}$.

It is seen that comprehensive removal of BSA from APTAC$75 \mathrm{H}$ crosslinked by 10 and 20 mol.\% of MBAA takes place during 3 times washing by $1 \mathrm{M} \mathrm{NaCl}$. Approximately $82-84 \%$ of BSA is desorbed from the molecularly-imprinted APTAC-75H. Figure 4 demonstrates the amount of adsorbed and desorbed BSA by APTAC-75H the cavity of which was preliminary adjusted to BSA. Charge density in APTAC-75H plays the crucial role in adsorption of BSA. APTAC- $75 \mathrm{H}$ with charge density 20 mol.\% much higher retains BSA (306 mg) compared to APTAC-75H containing 10 mol.\% of ionic monomers.

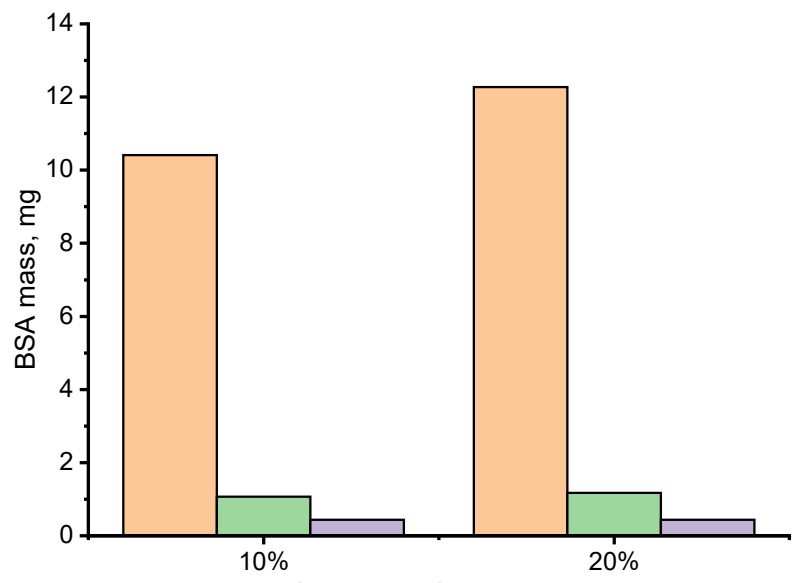

Hydrogel APTAC 75 - AMPSNa 25, charge density

Figure 3 - Amount of BSA washed out from the APTAC-75H crosslinked by 10 and 20 mol.\% of MBAA during three times washing by $1 \mathrm{M}$ solution of $\mathrm{NaCl}$

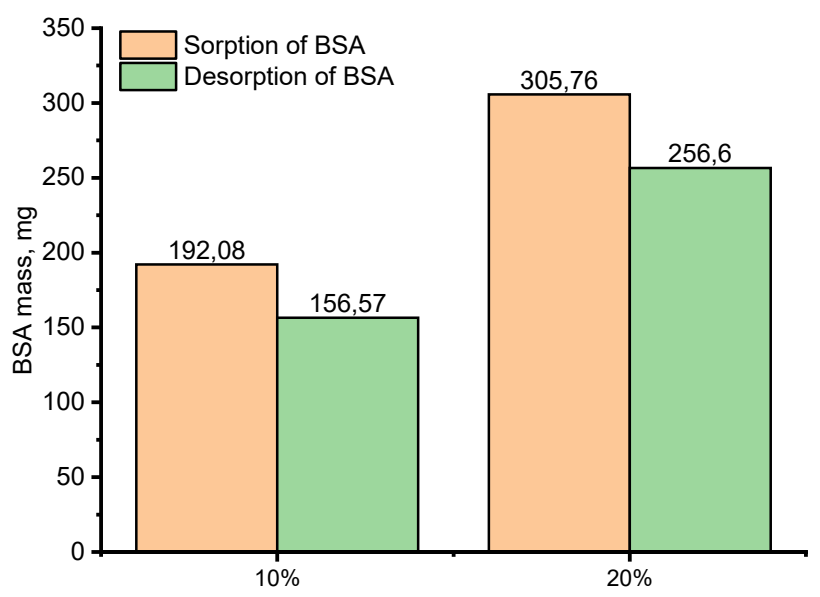

Hydrogel AAm-(APTAC 75 - AMPSNa 25), charge density

Figure 4 - Sorption to and desorption from molecularlyimprinted samples of APTAC-75H preliminary adjusted to BSA.

The crosslinking degree of APTAC- $75 \mathrm{H}$ is 10 and 20 mol.\% 
Analogous experiments were carried out with lysozyme that is positively charged at initial pH 6.57 (Figures 5,6 ). It is seen that comprehensive removal of lysozyme from AMPS-75H crosslinked by 10 and 20 mol.\% of MBAA takes place during 3 times washing by $1 \mathrm{M} \mathrm{NaCl}$. Adsorption of lysozyme on AMPS$75 \mathrm{H}$ is much lower and in the range of $66-74.8 \mathrm{mg}$ irrespective the charge density. Approximately $74-85.7 \%$ of lysozyme is washed out from the molecularly-imprinted AMPS- $75 \mathrm{H}$ by $1 \mathrm{M}$ $\mathrm{NaCl}$.

Table 2 represents the results of sorption of BSA and lysozyme on APTAC-75H imprinted for BSA and AMPS-75H imprinted for lysozyme.

Table 2 - Sorption of BSA and lysozyme on APTAC-75H and AMPS-75H imprinted for BSA and lysozyme

\begin{tabular}{llll}
\hline Protein & Concentration, $\%$ & Sorption, $\%$ & Sorption, $\mathrm{mg} / \mathrm{g}$ \\
\hline \multirow{2}{*}{ Lysozyme } & \multicolumn{3}{c}{ APTAC-75H } \\
\cline { 2 - 4 } & 0.1 & 1.02 & 7.58 \\
\hline \multirow{2}{*}{ BSA } & \multicolumn{3}{c}{ AMPS-75H" } \\
\cline { 2 - 4 } & 0.1 & No sorption & No sorption \\
\hline
\end{tabular}

As seen from Table 2 the positively charged lysozyme at $\mathrm{pH} 6.57$ is not adsorbed on positively charged APTAC-75H while the negatively charged BSA at pH 6.57 is not adsorbed on AMPS$75 \mathrm{H}$ that has the negatively charged matrix. However it should be noted that some parts of proteins can be retained on the "dead" volumes of hydrogels as a result of mechanical capturing or physically adsorption on the surface of hydrogels.

Separation of the mixture of BSA and lysozyme by MIPs adjusted to either BSA (APTAC-75H) or lysozyme (AMPS-75H) was complicated due to complex formation between two proteins in the range of $\mathrm{pH} 7.5-10.8$. Our results are in good agreement with data of authors [18].

Table 3 shows the results of selective adsorptiondesorption cycles of BSA on imprinted for BSA APTAC-75H polyampholyte hydrogel and selective adsorption-desorption cycles of lysozyme on imprinted for lysozyme AMPS-75H polyampholyte hydrogel from the mixture of BSA and lysozyme when the solution is turbid due to complexation of proteins (formation coacervate complexes) in the range of $\mathrm{pH}$ 7.4-10.8.

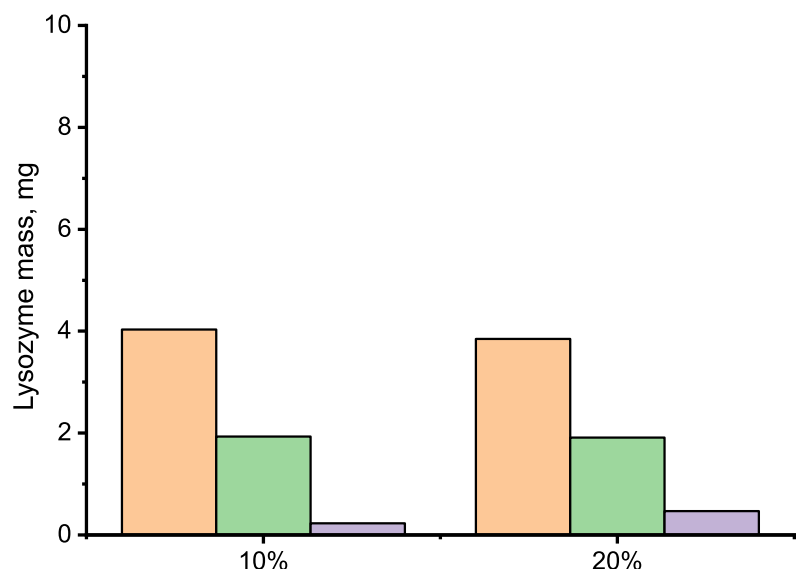

Hydrogel APTAC 25 - AMPSNa 75, charge density

Figure 5 - Amount of lysozyme washed out from the AMPS$75 \mathrm{H}$ hydrogel matrix crosslinked by 10 and 20 mol.\% of MBAA during three times washing by $1 \mathrm{M}$ solution of $\mathrm{NaCl}$

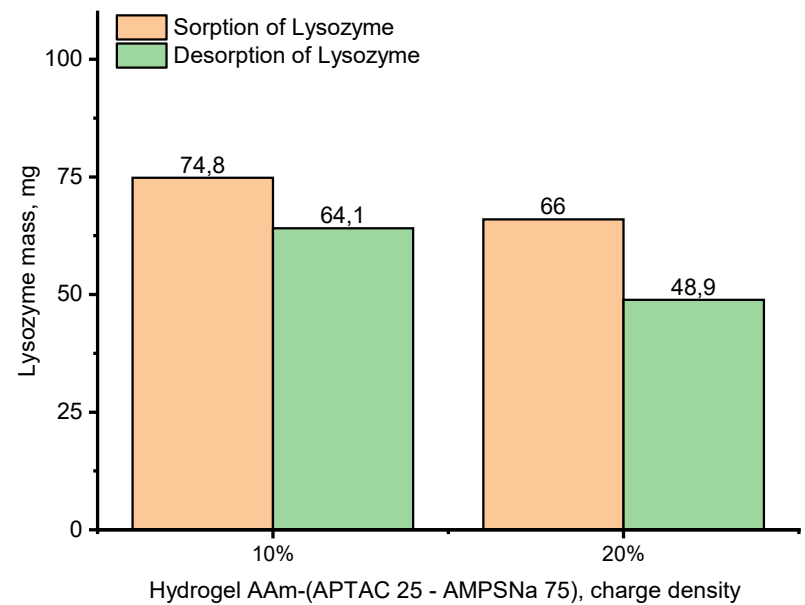

Figure 6 - Sorption to and desorption from molecularlyimprinted samples of AMPS-75H preliminary adjusted to lysozyme. The crosslinking degree of AMPS-75H is 10 and $20 \mathrm{~mol} . \%$

In the course of sorption BSA-lysozyme complex by APTAC-75H or AMPS-75H it is expected at first the destruction of protein complex and then adsorption of the target protein.

Table 3 - Cyclic selective sorption-desorption of BSA and lysozyme from their mixture by molecularly-imprinted polyampholyte hydrogels (MIPH) AMPS-75 and APTAC-75

\begin{tabular}{llllll}
\hline MIP/ & Cycle 1 & & Cycle 2 & & Cycle 3 \\
\cline { 2 - 6 } Protein & Sorption, & $\begin{array}{l}\text { Desorption, } \\
\mathrm{mg} / \%\end{array}$ & $\begin{array}{l}\text { Sorption, } \\
\mathrm{mg}\end{array}$ & $\begin{array}{l}\text { Desorption, } \\
\mathrm{mg} / \%\end{array}$ & $\begin{array}{l}\text { Sorption, } \\
\mathrm{mg}\end{array}$ \\
\hline APTAC-75H/BSA & 20.37 & $16.7 / 82$ & 15.42 & $13.41 / 87$ & 12.01 \\
AMPS-75H/Lysozyme & 9.52 & $7.9 / 83$ & 6.31 & $5.55 / 88$ & 4.64 \\
\hline
\end{tabular}


Table 4 - Sorption efficiency of MIP hydrogels with respect to proteins and drugs.

\begin{tabular}{|c|c|c|c|}
\hline MIP hydrogels & Protein or drug & Sorption, mg/g & Reference \\
\hline APTAC-75H & BSA & 3060 & present work \\
\hline AMPS-75H & Lysozyme & $660-750$ & \\
\hline AAm-MAA-DMAEMA ${ }^{a}$ & Lysozyme & 22 & 19 \\
\hline AAm-MAA-DMAEMA ${ }^{\mathrm{a}, \mathrm{d}}$ & & $<10$ & \\
\hline AAm-MAA-DMAEMA ${ }^{\mathrm{b}}$ & & 431 & \\
\hline AAm-MAA-DMAEMA ${ }^{\mathrm{b}, \mathrm{d}}$ & & 150 & \\
\hline AAm-MAA-DMAEMA' & & 125 & \\
\hline AAm-MAA-DMAEMA ${ }^{c, d}$ & & 44 & \\
\hline NIPA-APMA-Ibue & Ibuprofen & 275 & 20 \\
\hline NIPA-AAc-Prop ${ }^{f}$ & Propranolol & 80 & \\
\hline M15M'01DC05L10g & Lysozyme & 39 & 21 \\
\hline M15M'02DC05L10g & & 199 & \\
\hline M15M’05DC05L10g & & 313 & \\
\hline AAm-NIPAAm-DMC-AMPS-MBAAm & BSA & 1,7 & 22 \\
\hline AAm-NIPAAm-DMC-AMPS-MBAAm & Lysozyme & 0,75 & \\
\hline AAm-NIPAAm-DMC-AMPS-MBAAm & Ovalbumin & 0,7 & \\
\hline
\end{tabular}

a-monomer concentration in hydrogel is $4 \% \mathrm{w} / \mathrm{w}$.

$\mathrm{b}-$ monomer concentration in hydrogel is $20 \% \mathrm{w} / \mathrm{w}$.

c-monomer concentration in hydrogel is $40 \% \mathrm{w} / \mathrm{w}$.

$\mathrm{d}$ - runs are carried out at the different concentration of aqueous $\mathrm{NaCl}$ solution.

e-hydrogels were immersed $4.75 \mathrm{mM}$ drug aqueous solutions at $4^{\circ} \mathrm{C}$

$\mathrm{f}$ - hydrogels were immersed $1 \mathrm{mM}$ drug aqueous solutions at $4^{\circ} \mathrm{C}$

$\mathrm{g}$ - hydrogel based on NIPAAm-MAA-MBAAm

Table 4 shows the sorption capacity of different MIP hydrogels tested with respect to various proteins and drugs. It is seen that MIP hydrogels based on APTAC-75H and AMPS-75H demonstrate considerable high efficiency towards BSA and lysozyme respectively in comparison with described in literature.

\section{Conclusion}

Molecularly-imprinted polyampholyte hydrogels AMPS$75 \mathrm{H}$ and APTAC-75H are proved effective tool for separation of the mixture of BSA and lysozyme. The cyclic selective sorptiondesorption of BSA and lysozyme from their mixture is in the range of $78-84 \%$ and clearly demonstrates the separation of target proteins by MIP.

\section{Acknowledgements}

This research was funded by the Science Committee of the Ministry of Education and Science of the Republic of Kazakhstan (Grant No. IRN AP05131003).

\section{References (GOST)}

1 Lozinsky V.I. Cryogels on the basis of natural and synthetic polymers: Preparation, properties and areas of implementation // Russian Chemical Reviews. - 2002. - Vol.71. - P.489-511.

2 Janiak D.S., Ayyub O.B., Kofinas P. Effects of charge density on the recognition properties of molecularly imprinted polyampholyte hydrogels // Polymer. - 2010. - Vol.51. - P.665-670.

3 Lago M.A., Grinberg V.Ya., Burova T.V., Concheiro A., Alvarez-Lorenzo C. Ionic and polyampholyte N-isopropylacrylamidebased hydrogels prepared in the presence of imprinting ligands: Stimuli-responsiveness and adsorption/release properties // Journal of Functional Biomaterials. - 2011. - Vol.2. - P.373-390.

4 Yang C., Zhou X-L., Liu Y-R., Wang J., Tian L-L., Zhang Y., Hu X-Y. Charged groups synergically enhance protein imprinting in amphoteric polyacrylamide cryogels // Journal of Applied Polymer Science. - 2016. - Vol.133. - ID.43851.

5 Huang J.T., Zhang, J., Zhang J.Q., Zheng S.H. Template imprinting amphoteric polymer for the recognition of proteins // Journal of Applied Polymer Science. - 2005. - Vol.95. - P.358-361.

6 Haag S.L., Barnards M.T. Polyampholyte hydrogels in biomedical applications // Gels. - 2017. - Vol.3. - ID.41.

7 Kudaibergenov S.E., Tatykhanova G.S., Klivenko A.N. Complexation of macroporous amphoteric cryogels based on N,Ndimethylaminoethylmethacrylate and methacrylic acid with dyes, surfactant, and protein // Journal of Applied Polymer Science. - 2016. - Vol.133. - ID.43784. 
8 Yang C., Zhou X.L., Liu Y.R., Zhang Y., Yan Y.N. Extensive imprinting adaptability of polyacrylamide-based amphoteric cryogels against protein molecules // Chinese Journal of Analytical Chemistry. - 2016. - Vol.44. - P.1322-1327.

9 Kanazawa R., Sasaki A., Tokuyama H. Preparation of dual temperature/pH-sensitive polyampholyte gels and investigation of their protein adsorption behaviors // Separation and Purification Technology. - 2012. - Vol.96. - P.26-32.

10 Ou S.H., Wu M.C., Chou T.C., Liu C.C. Polyacrylamide gels with electrostatic functional groups for the molecular imprinting of lysozyme // Analytica Chimica Acta. - 2004. - Vol.504. - P.163-166.

11 Yang C., Zhou X.L., Liu Y.R., Zhang Y., Yan Y.N. Extensive Imprinting Adaptability of Polyacrylamide-based Amphoteric Cryogels Against Protein Molecules // Chinese Journal of Analytical Chemistry. - 2016. - Vol.44. - P.1322-1327.

12 Ying X., Zhu X., Li D., Li X. Preparation and specific recognition of protein macromolecularly imprinted polyampholyte hydrogel // Talanta. - 2019. - V.192. - P.14-23.

13 Toleutay G., Shakhvorostov A., Kabdrakhmanova S., Kudaibergenov S. Solution behavior of quenched or strongly charged polyampholytes in aqueous-salt solutions // Bulletin of the Karaganda University. Chemistry Series. - 2019. - Is.2. - P.35-44.

14 Toleutay G., Su E., Okay O., Kudaibergenov S.E. Swelling and mechanical properties of quenched polyampholyte hydrogels based on 2-acrylamido-2-methyl-1-propanesulfonic acid sodium salt (AMPS) and (3-acrylamidopropyl) trimethylammonium chloride (APTAC) // Bulletin Karaganda University. Chemistry Series. - 2019. - Is.4. - P.35-43.

15 Toleutay G., Dauletbekova M., Shakhvorostov A., Kudaibergenov S. Quenched Polyampholyte Hydrogels Based on (3-Acrylamidopropyl)trimethyl Ammonium Chloride and Sodium Salt of 2-Acrylamido-2-methyl-1-Propanesulfonic // Macromolecular Symposia. - 2019. - Vol.385. - ID.1800160.

16 Toleutay G., Su E., Kudaibergenov S., Okay O. Highly stretchable and thermally healable polyampholyte hydrogels via hydrophobic modification // Colloid and Polymer Science. - 2020. - Vol.298. - P.273-284.

17 Kudaibergenov S.E., Okay O. Behaviors of quenched polyampholytes in solution and gel state // Polymers for Advanced Technologies. - 2020. - P.1-16.

18 Wetter L.R., Deutsch H.F. Immunological studies on egg white proteins IV. Immunochemical and physical studies of lysozyme // Journal of Biological Chemistry. - 1951. - Vol.192. - P.237-242.

19 Ou S.H., Wu M.C., Chou T.C., Liu C.C. Polyacrylamide gels with electrostatic functional groups for the molecular imprinting of lysozyme // Analytica Chimica Acta. - 2003. - Vol.504. -- P.163-166.

20 Lago MA, Grinberg VY, Burova TV, Concheiro A, Alvarez-Lorenzo C. Ionic and polyampholyte N-isopropylacrylamide-based hydrogels prepared in the presence of imprinting ligands: stimuli-responsiveness and adsorption/release properties // J Funct Biomater. - 2011. - Vol.2, Is.4. - P.373-90.

21 Nadia Adrus, Mathias Ulbricht Molecularly imprinted stimuli-responsive hydrogels for protein recognition // Polymer. - 2012. - V.53, Is.20. - P.4359-4366.

22 Ying X, Zhu X, Li D, Li X. Preparation and specific recognition of protein macromolecularly imprinted polyampholyte hydrogel // Talanta. - 2019. - Vol.192. - P.14-23.

\section{References}

1 Lozinsky V (2002) Russ Chem Rev 71:489-511. http://doi.org/10.1070/RC2002v071n06ABEH000720

2 Janiak D, Ayyub O, Kofinas P (2010) Polymer 51:665-670. https://doi.org/10.1016/j.polymer.2009.12.022

3 Lago M, Grinberg V, Burova T, et al (2011) Journal of Functional Biomaterials 2:373-390. https://doi.org/10.3390/jfb2040373

4 Yang C, Zhou X, Liu Y, et al (2016) J Appl Polym Sci 133:43851. https://doi.org/10.1002/app.43851

5 Huang J, Zhang, Zhang J, et al (2005) J Appl Polym Sci 95:358-361. https://doi.org/10.1002/app.21262

6 Haag S, Barnards M (2017) Prog Coll Pol Sci S 3:41. https://doi.org/10.3390/gels3040041

7 Kudaibergenov S, Tatykhanova G, Klivenko A (2016) J Appl Polym Sci 133:43784. https://doi.org/10.1002/app.43784

8 Yang C, Zhou X, Liu Y, et al (2016) Chinese J Anal Chem 44:1322-1327. https://doi.org/10.1016/S1872-2040(16)60954-4

9 Kanazawa R, Sasaki A, Tokuyama H (2012) Sep Purif Technol 96:26-32. https://doi.org/10.1016/j.seppur.2012.05.016

10 Ou S., Wu M., Chou T, et al (2004) Anal Chim Acta 504:163-166. https://doi.org/10.1016/S0003-2670(03)00531-2

11 Yang C, Zhou X, Liu Y, et al (2016) Chinese J Anal Chem 44:1322-1327. https://doi.org/10.1016/S1872-2040(16)60954-4

12 Ying X, Zhu X, Li D, et al (2019) Talanta 192:14-23. https://doi.org/10.1016/j.talanta.2018.08.084

13 Toleutay G, Shakhvorostov A. Kabdrakhmanova S et al (2019) Bulletin of Karaganda University. Chemistry Series 2:35-44. https://doi.org/10.31489/2019Ch2/35-44

14 Toleutay G, Su E, Okay O., Kudaibergenov S (2019) Bulletin of Karaganda University. Chemistry Series 4:35-43. https://doi. org/10.31489/2019Ch4/35-43

15 Toleutay G, Dauletbekova M, Shakhvorostov Aetal (2019) Macromol Symp 385:1800160. https://doi.org/10.1002/masy.201800160

16 Toleutay G, Su E, Kudaibergenov S (2020) Colloid Polym Sci 298:273-284. https://doi.org/10.1007/s00396-020-04605-8

17 Kudaibergenov S, Okay O (2020) Polym Advan Technol 1-16. https://doi.org/10.1002/pat.5112 
18 Wetter L, Deutsch H (1951) J Biol Chem 192:237-242. https://doi.org/10.1016/S0021-9258(18)55926-3

19 Ou S, Wu M, Chou T, et al (2003) Anal Chim Acta 504:1:163-166. https://doi.org/10.1016/S0003-2670(03)00531-2

20 Lago M, Grinberg V, Burova T, et al (2011) J Funct Biomater 2:4:373-90. https://doi.org/10.3390/jfb2040373

21 Nadia A, Mathias U (2012) Polymer 53:20:4359-4366. https://doi.org/10.1016/j.polymer.2012.07.062

22 Ying X, Zhu X, Li D, et al (2019) Talanta 192:14-23. https://doi.org/10.1016/j.talanta.2018.08.084 